\title{
Chapter 4 \\ Emerging States in Latin America: How and Why They Differ from Their Asian Counterparts
}

\author{
Keiichi Tsunekawa
}

Many works have been written on the middle-income trap as one of the biggest challenges for emerging states, most of which are middle-income countries (refer to Chap. 1). In the Asian Development Bank's (ADB's) Asia 2050 report, the authors warn that even the Asian emerging states that have had the strongest economic performances may be in danger of falling into the trap. They believe that outside of Asia, some countries have already fallen into the trap; they cite Brazil and South Africa as the typically trapped countries (Kohli et al. 2011, p. 54). As many other emerging states in Latin America have development patterns similar to that of Brazil, they may also have fallen into economic difficulty. The purpose of this chapter is to analyze the pattern of the economic development of the emerging states in Latin America in comparison with their counterparts in Asia and to elucidate why the economic performance of the emerging states in Latin America has differed from that of Asia.

In the first section, I use the long-term data on the size of each country's gross domestic product (GDP) per capita relative to that of the United States to examine each country's catchup speed with the advanced industrial countries. The data reveal that the performance of Latin American countries in terms of catchup speed has been by far slower than that of their Asian counterparts. In Sect. 4.2, I then examine immediately observable (first-order), mostly economic causes of Latin America's poor economic performance by focusing on each country's changing sectoral competitiveness. I illustrate that Latin American countries increasingly depend on natural resource and resource-processing sectors, whereas Asian countries have seen the expansion of machinery industries with higher value added. In Sect. 4.3, I deepen the analysis by looking into the second-order (political economy) causes of the difference in their performance. I examine why Latin America has been deepening its dependence on natural resources, and I point out low research and development

K. Tsunekawa $(\varangle)$

Political-Economy Studies, National Graduate Institute for Policy Studies, Tokyo, Japan

e-mail: k-tsunekawa@grips.ac.jp

K. Tsunekawa and Y. Todo (eds.), Emerging States at Crossroads,

Emerging-Economy State and International Policy Studies,

https://doi.org/10.1007/978-981-13-2859-6_4 
(R\&D) expenditure, excessive consumption, weak intrafirm connections, low trust among people, and the middling effectiveness of public administration. In Sect. 4.4, I touch on the root (historical) causes of the contemporary Latin American difficulties, looking at several historical legacies from the colonial period, the postindependence period, the late nineteenth and early twentieth centuries, and the World War II and post-World War II periods.

\subsection{Different Economic Performance}

This chapter measures the "emerging" phenomenon by economic catchup speed. In the top panel of Fig. 4.1, which reveals the GDPs per capita of some Latin American countries (and South Africa) as a percentage of the United States' GDP, three catchup periods can be discerned. During the late nineteenth century and the early twentieth century, Argentina, Mexico, Chile (to a lesser degree), and Peru (during the slightly later period) experienced relative improvements in their GDPs per capita. This was the period in which Latin America witnessed the expansion of the export of mineral and agricultural products to then-industrializing Europe and the United States. The second "emerging" phenomenon occurred between the 1950s and 1970s in Mexico and Brazil, the countries that pursued import substitution industrialization most vigorously. The third catchup was observed during the 2000s, mostly thanks to the commodity boom that benefited the resource-rich countries in Latin America. However, each period of upsurge was followed by a period of decline, and despite the recent improvement, the relative GDPs per capita of Latin American countries have never regained their historical peaks.

In contrast, the emerging states in Asia began their catchup endeavor only after World War II but have improved their relative GDPs per capita constantly for the past half a century (as seen in the lower panel of Fig. 4.1). ${ }^{1}$ It is undebatable that the emerging states in Latin America have had much poorer performance compared with their Asian counterparts for the past thirty to forty years.

\subsection{First-Order Causes: Competitiveness of Manufacturing Industries}

Latin American countries' weak economic performance can be explained by weak productivity improvement in the national economies stemming from their manufacturing industries' inadequate competitiveness. Within the manufacturing industries, the degrees of value-addedness are expected to rise as the leading sectors shift from light manufacturing (such as apparel and footwear) to heavy and chemical indus-

\footnotetext{
${ }^{1}$ Consequently, Singapore, Taiwan, and South Korea surpassed Latin American countries during the 1980s, whereas Malaysia, Thailand, and China caught up with them by 2010 .
} 

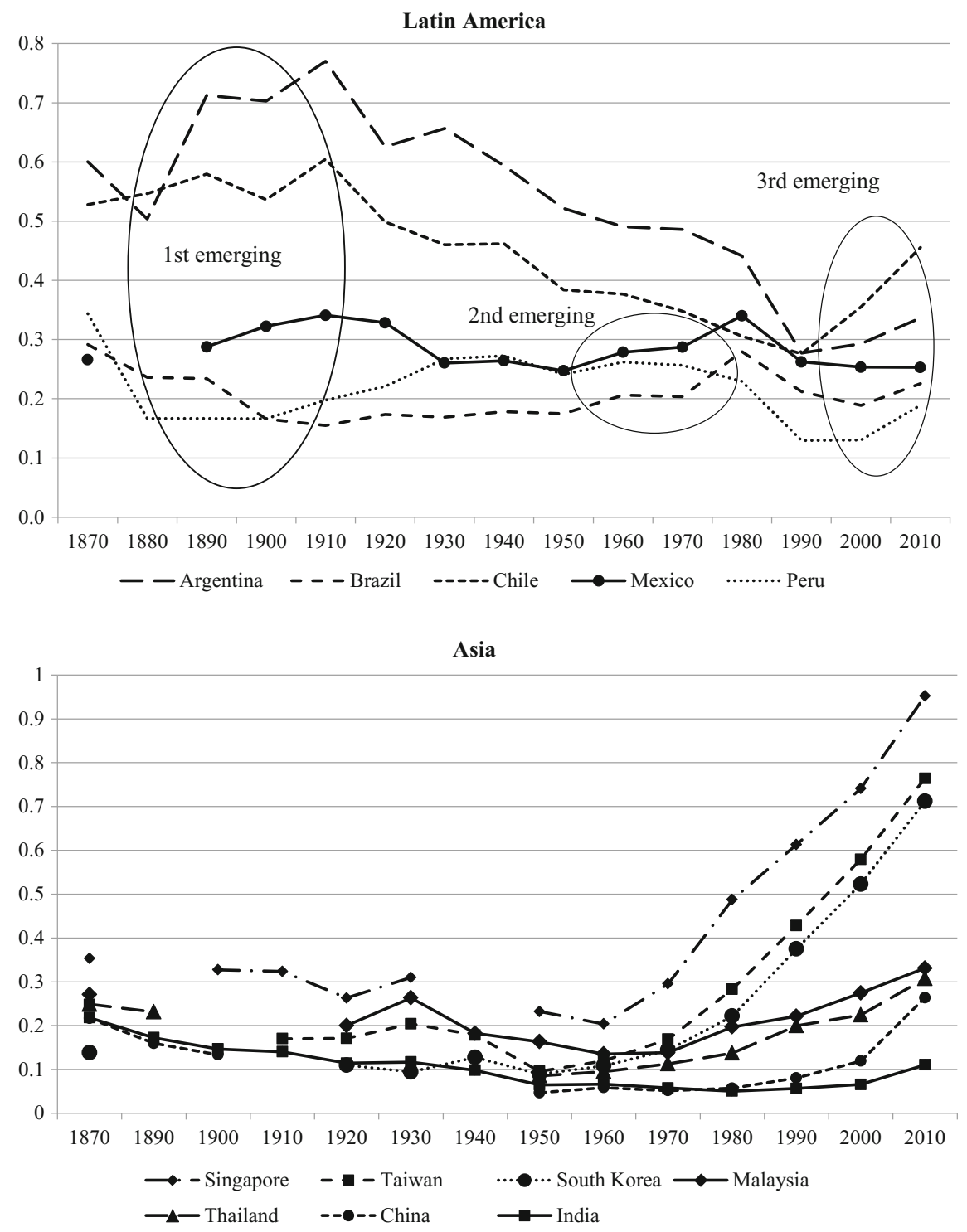

Fig. 4.1 Relative size of GDP per capita (United States =1.0). Source Constructed by the author on the basis of data retrieved from the Maddison project database. http://www.ggdc.net/maddison/ maddison-project/data.htm. Accessed 20 November 2016

tries, and to information and communication technology (ICT)-integrated machinery industries. This is because the value chain generally becomes more complex and extensive and provides greater value-addedness as a country's industrial structure steps up from the former to the latter industrial sectors. 


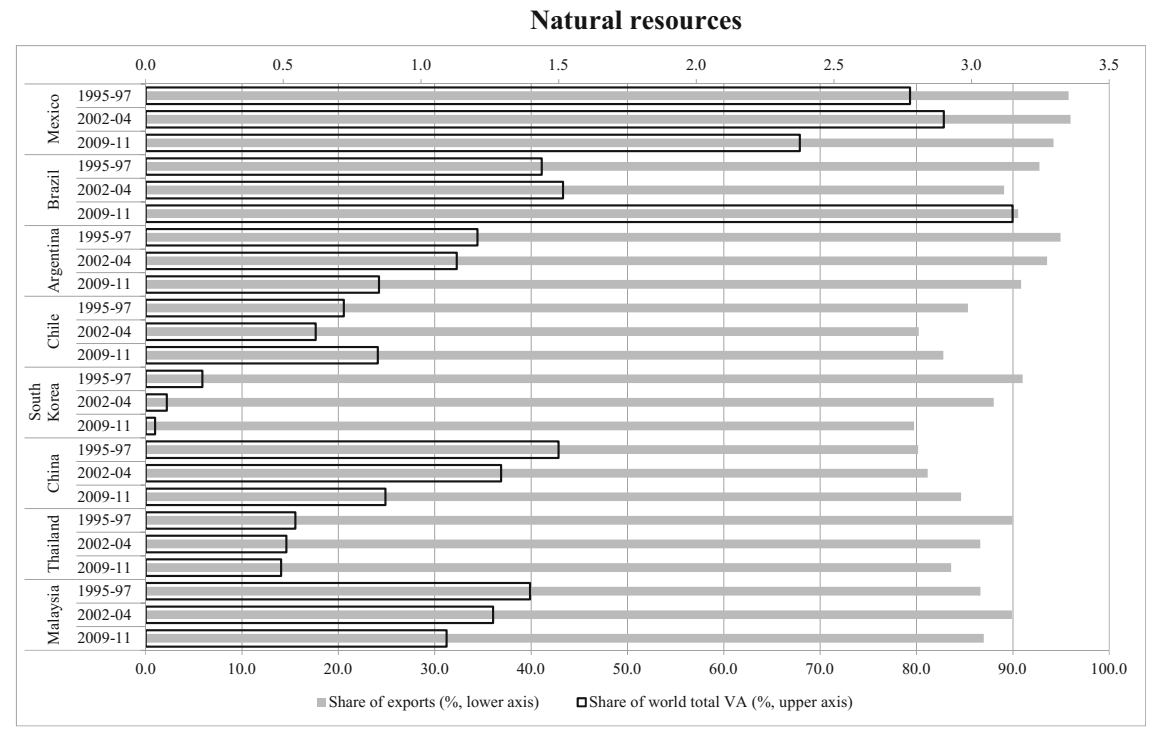

Food products, beverages, and tobacco

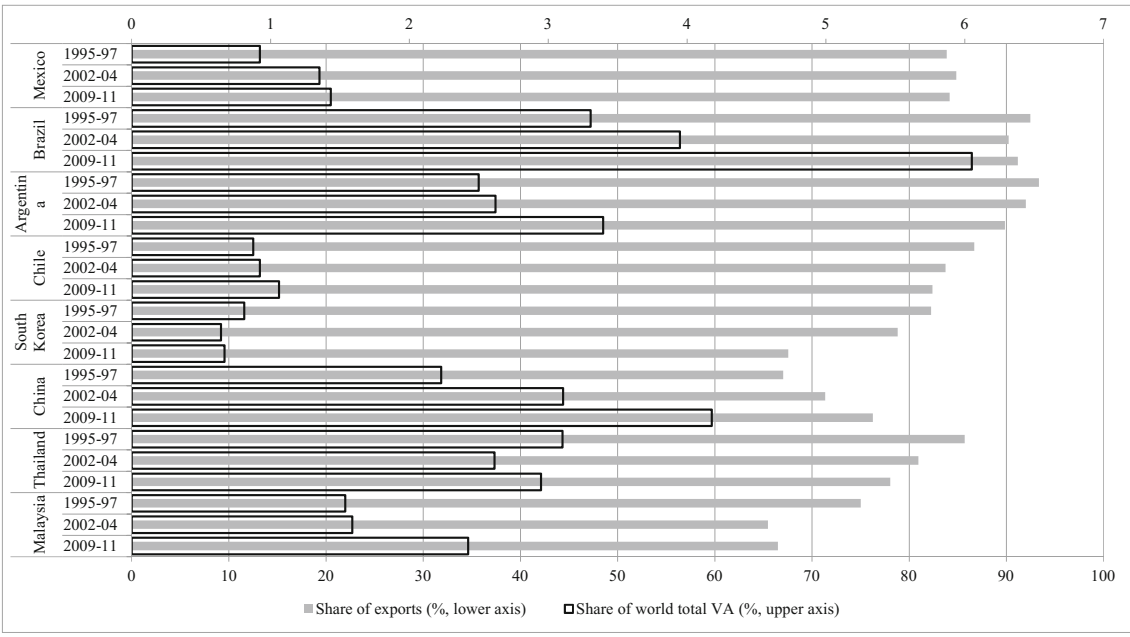

Fig. 4.2 Value added as shares of exports and of the world total value added in selected sectors (\%). Source Constructed by the author on the basis of data retrieved from OECD's TiVA database. https://stats.oecd.org/index.aspx?queryid=75537. Accessed 20 September 2017

Figure 4.2 displays each country's value added in the export of natural resources, food products, and machinery as the share of the country's sectoral export (local content) and as the share of the entire world value added in the given sector. The food product sector represents the light industries; it can also be regarded as a resourceprocessing industry, as it uses domestic raw materials in many countries. 
Transport, electrical, and other machines and equipment

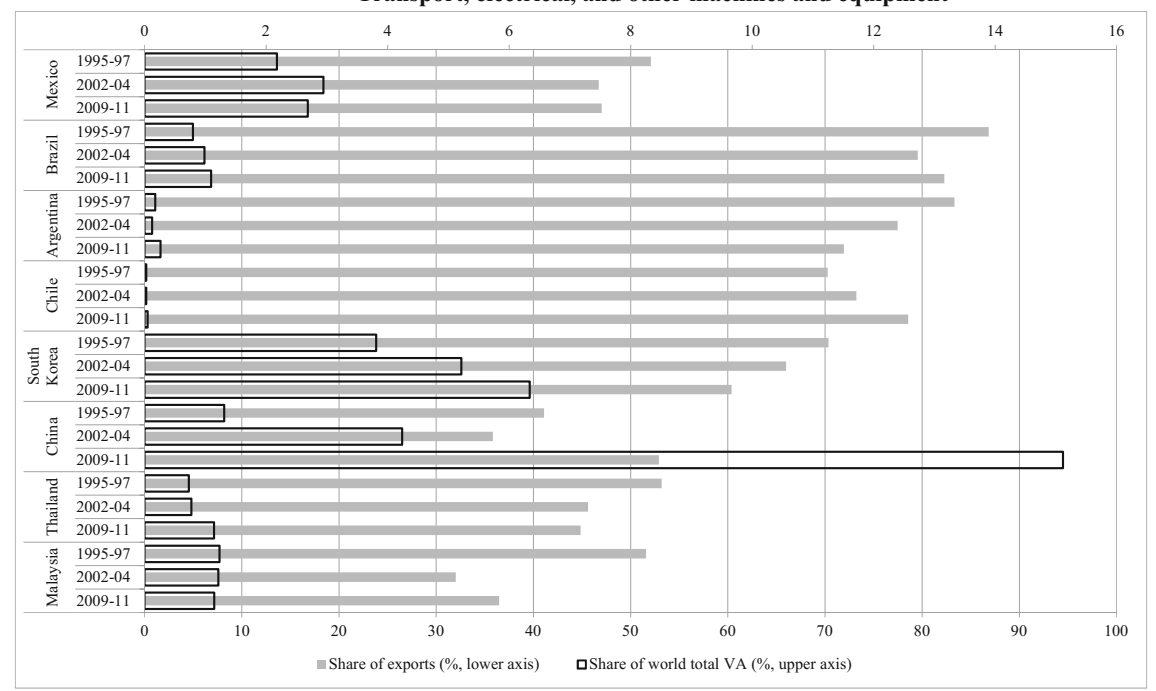

Fig. 4.2 (continued)

This figure indicates that the local content is high (around 90\%) in the natural resource sector in all of the countries, but the share of the world total is especially high in Mexico and Brazil because the absolute amount of the export of natural resources from these countries is large. The food product sector reveals a slightly different pattern. The local content is low in South Korea, China, and Malaysia, but their share of the world value added is high except for in South Korea. The share of the world value added is also high in Brazil, Argentina, and Thailand. These countries (except for South Korea) are those endowed with rich agricultural resources. It can be concluded from these data that resource-rich countries have relatively high competitiveness in the natural resource sector and/or the resource-processing sector.

The machinery sector presents a different picture. Asian countries have local content that is lower than that of Latin American countries (except for Mexico), but South Korea and China have high and increasing shares of value added in the world. However, Malaysia's and Thailand's shares are smaller than Mexico's share and are similar to Brazil's. This is one of the reasons why a fear of the middle-income trap is in the air in Malaysia and Thailand. However, the fact that the Malaysian and Thai shares of value added in the world are similar to Brazil's share but their local contents are lower than Brazil's simply indicates that the absolute amount of machinery export is greater in the Southeast Asian countries. It can be concluded that, generally speaking, Asia has more robust machinery industries than Latin America does.

Figure 4.2, however, reveals a limitation in measuring various countries' competitiveness because a large world share of value added in a certain sector could simply mean that a country exports low-value-added products in a huge quantity. In 
contrast, a small world share of value added (such as the one for the natural resource sector in South Korea) does not necessarily indicate a lack of competitiveness but simply the scarcity of exportable resources. To examine the sectoral competitiveness in each country, I present here another measure called the comparative advantage measured by sectoral value added in export (CASVA). As its name indicates, the CASVA is calculated on the basis of value added in a country's exports. First, the ratio of each country's value added in a specific economic sector to the total value added in the country's overall exports is calculated. Then, the result is divided by the ratio of the world value added in this sector to the total value added in export. ${ }^{2}$ If the consequent CASVA figure is greater than 1.0, this indicates that the sector records a rate of value added higher than the world average, and therefore, it is relatively competitive in the world. The CASVA indicates sectoral competitiveness only and cannot serve as an indicator that directly compares the competitiveness of national economies. However, it can reveal which country is competitive in each sector and which sector has higher competitiveness in each national economy. Figure 4.3 thus complements the information presented in Fig. 4.2.

Figure 4.3 reveals the CASVA in several Latin American and Asian countries. It clearly indicates that the natural resource sector and/or resource-processing sector (food products, wood products, and metal products) are competitive in Latin American economies. Chile and Brazil have diversified processing sectors, whereas Argentina concentrates on food products. Chile is especially prominent in its diversified and competitive processing sectors. Chile's CASVA in the metal processing sector is five times greater than the world average. The food processing and wood processing sectors are 2.5 times more competitive than the world average is. It is evident that Chile today is the best-performing catchup country in the region (see Fig. 4.1).

In contrast, the machinery industries ("Transport, electrical, and other machineries") are weak except for in Mexico, which benefits from the opportunities that the North American Free Trade Agreement (NAFTA) provides. Asian countries are generally strong in the machinery industries, although the advantage of Malaysia and Thailand is not noticeably big. It should also be noted that the textile industry is still quite competitive in Asian countries (except in Malaysia), although its relative importance is declining, which reflects the transformation of these countries' industrial structures from lower-valued-added sectors to higher-value-added ones. This phenomenon is especially conspicuous in South Korea and China. In contrast, Malaysia (and Thailand to a lesser extent) seems to increasingly resemble Latin American countries with respect to enhancing dependence on resource-processing industries, such as food products, wood products, and chemicals.

\footnotetext{
${ }^{2}$ Here, the value-addedness in exports is used instead of value-addedness in domestic production because information on export to the world market reflects each country's international competitiveness better than information on domestic production does. The CASVA is shown by the following specification: CASVA $=\mathrm{V}_{\mathrm{ij}} / \Sigma_{\mathrm{i}} \mathrm{V}_{\mathrm{ij}} \div \Sigma_{\mathrm{j}} \mathrm{V}_{\mathrm{ij}} / \Sigma_{\mathrm{ij}} \mathrm{V}_{\mathrm{ij}}$, where $\mathrm{V}_{\mathrm{ij}}$ indicates the value added (in exports) in the $\mathrm{i}$ sector of $\mathrm{j}$ country; $\Sigma_{\mathrm{i}} \mathrm{V}_{\mathrm{ij}}$ and $\Sigma_{\mathrm{j}} \mathrm{V}_{\mathrm{ij}}$ mean, respectively, the value added in all sectors of $\mathrm{j}$ country and the value added in i sector of all of the countries in the world; and $\Sigma_{\mathrm{ij}} \mathrm{V}_{\mathrm{ij}}$ is the value added in all sectors of all of the countries in the world.
} 


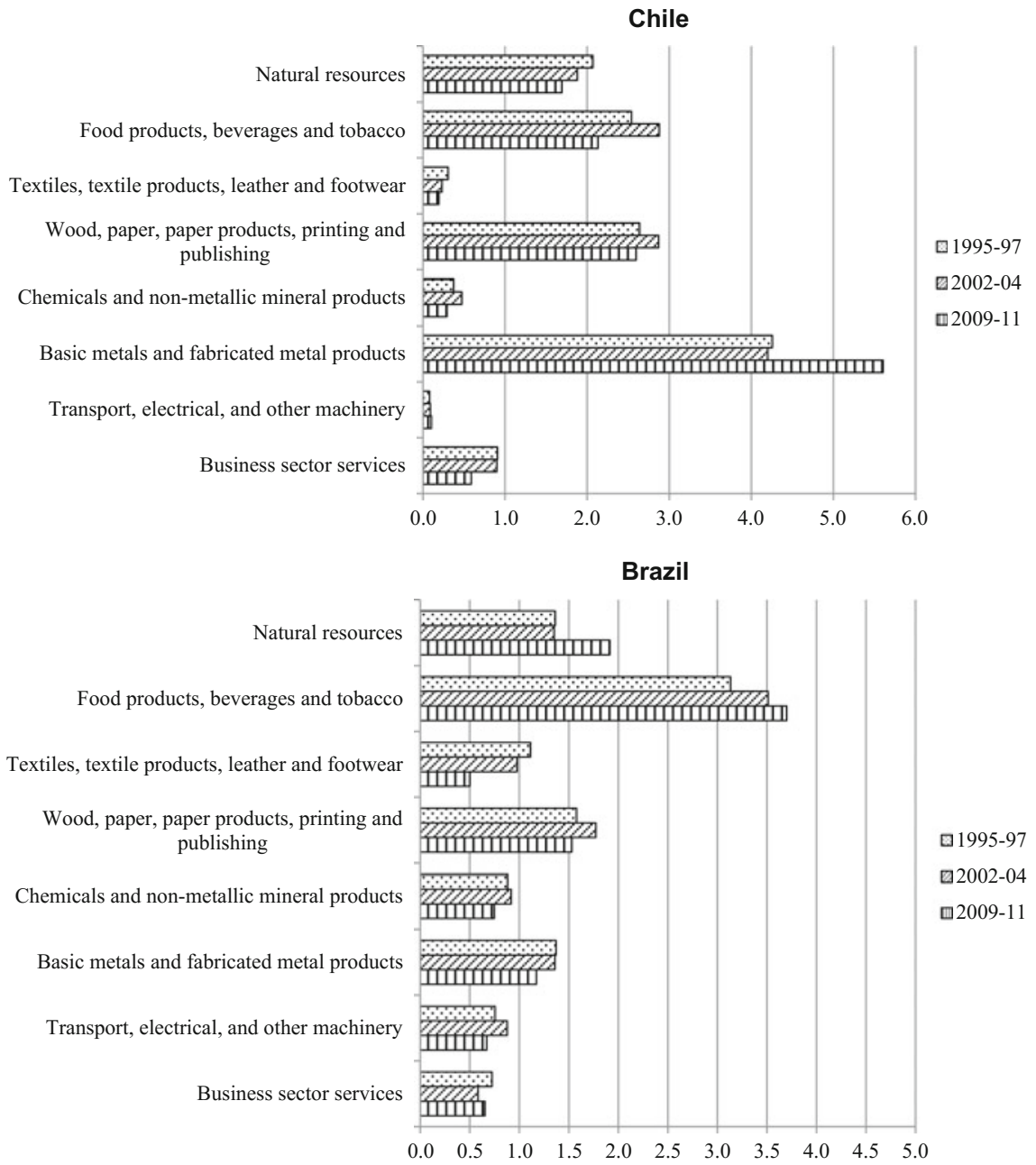

Fig. 4.3 CASVA. Source Constructed by the author on the basis of data retrieved from OECD's TiVA database. https://stats.oecd.org/index.aspx?queryid=75537. Accessed 20 September 2017

In summary, Latin American countries have deepened their dependence on the natural resource sector and on the resource-processing sector, whereas Asian countries have upgraded their industrial structures by shifting to the machinery industries. One of the exceptional cases in Latin America is Mexico, which has improved its competitiveness in the machinery industries. It should also be noted that the machinery industries' competitiveness is still limited in Southeast Asian countries. In general, however, it can be concluded that the slow and unstable catchup by Latin American countries stems from their failure to upgrade their industrial structures. In contrast, 


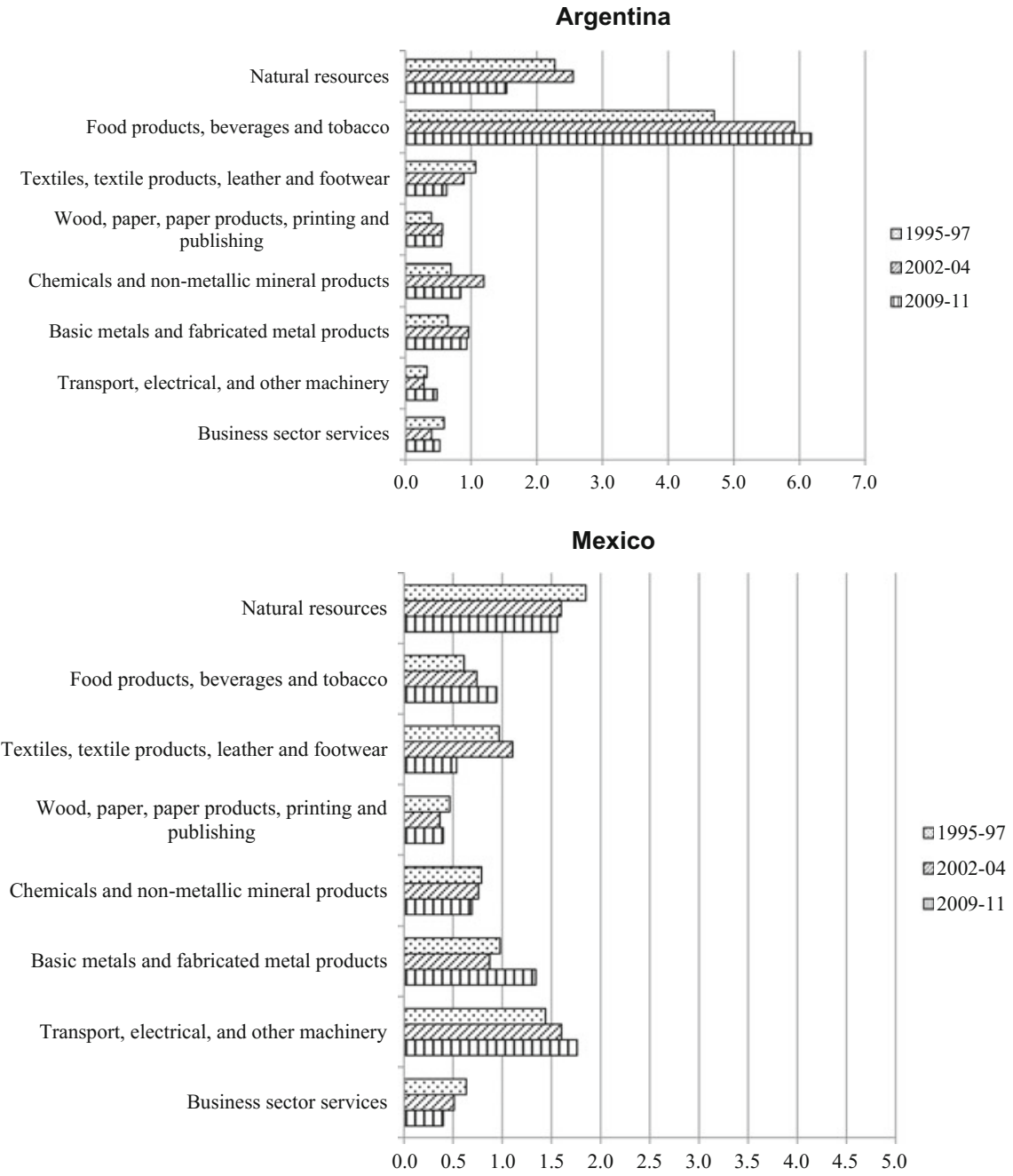

Fig. 4.3 (continued)

Asian countries have demonstrated a marked catchup speed thanks to the structural transformation of their economies from lower-value-added sectors to higher-valueadded sectors. 


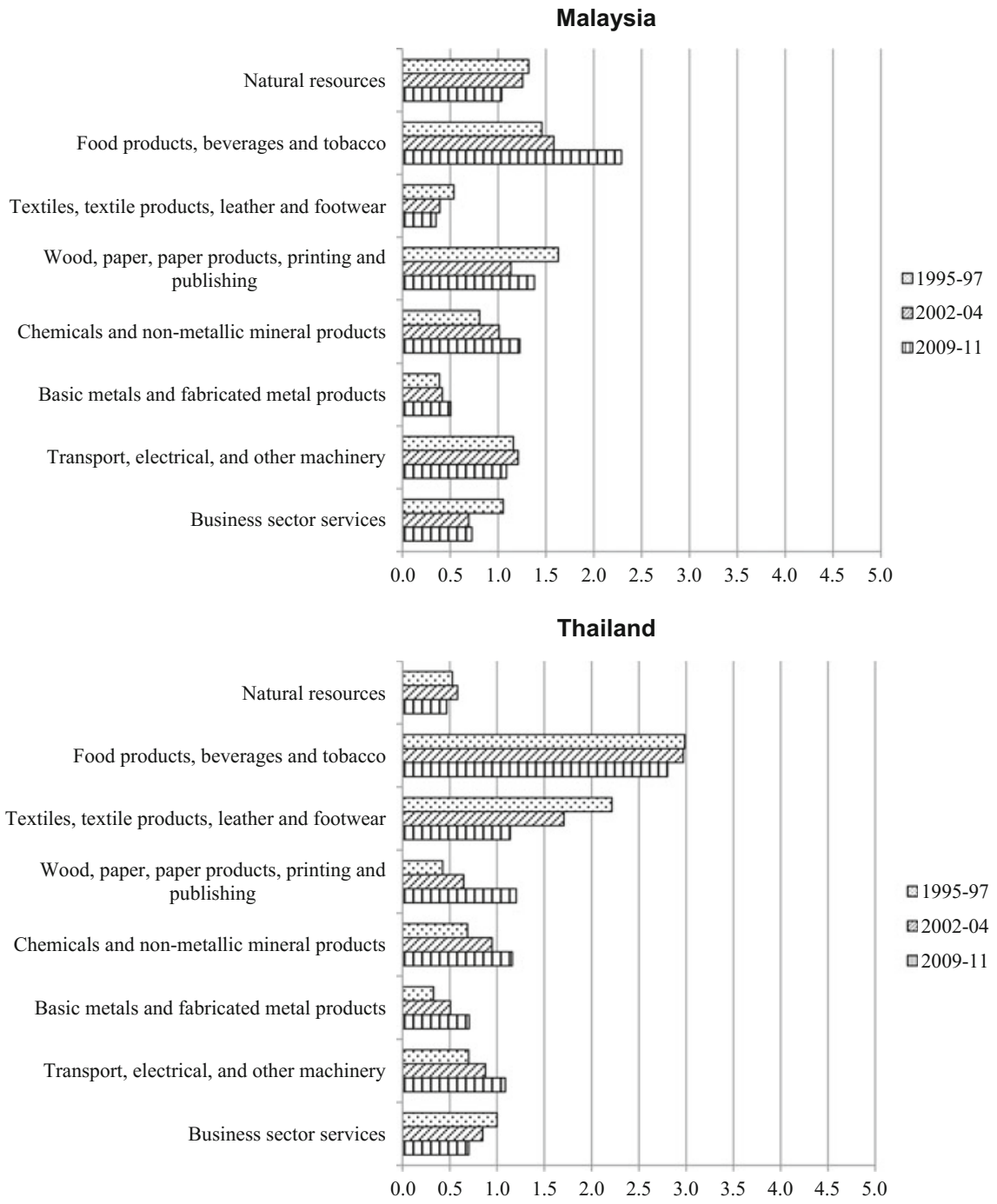

Fig. 4.3 (continued)

\subsection{Second-Order Causes: Political Economy}

The various patterns of industrial development in Latin America and Asia stem from several factors: R\&D expenditure, fixed capital formation, societal trust, the effectiveness of public administration, and intraregional trade. Higher performance in these factors helps to develop complex manufacturing industries with long value chains by fostering production networks within and beyond national borders. 

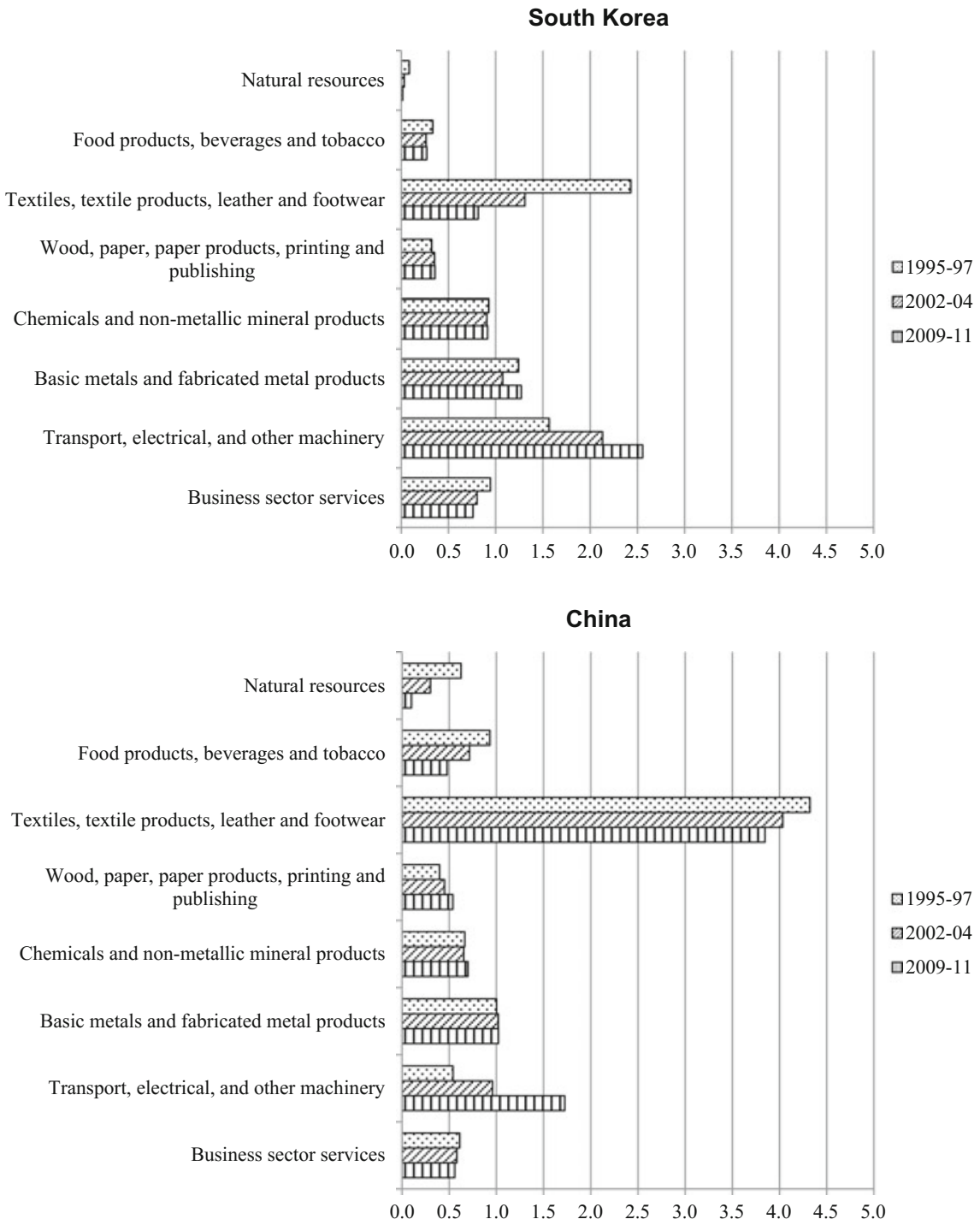

Fig. 4.3 (continued)

\subsubsection{R\&D and Education}

First, technological adaptation and innovation are crucial for the development of high-value-added manufacturing industries. To measure a country's technological capability, this chapter uses the R\&D expenditure/personnel and the records of the Organisation for Economic Co-operation and Development's (OECD's) Programme 
Table 4.1 R\&D expenditure/personnel and PISA scores

\begin{tabular}{|c|c|c|c|c|c|c|c|c|}
\hline & \multicolumn{2}{|c|}{$\begin{array}{l}\text { R\&D } \\
\text { expenditure per } \\
\text { GDP }(\%)\end{array}$} & \multicolumn{2}{|c|}{$\begin{array}{l}\text { R\&D personnel } \\
\text { per million } \\
\text { population }\end{array}$} & \multicolumn{2}{|c|}{ PISA-Math } & \multicolumn{2}{|c|}{ PISA-Science } \\
\hline & $2000-01$ & $2010-11$ & $2000-01$ & $2010-11$ & 2006 & 2012 & 2006 & 2012 \\
\hline Argentina & 0.42 & 0.54 & 999 & 1,670 & 381 & 388 & 391 & 406 \\
\hline Brazil & 1.03 & 1.14 & 760 & 1,343 & 370 & 391 & 390 & 405 \\
\hline Chile & & 0.35 & & 759 & 411 & 423 & 438 & 445 \\
\hline Colombia & 0.11 & 0.21 & & & 370 & 376 & 388 & 399 \\
\hline Mexico & 0.34 & 0.43 & 417 & & 406 & 413 & 410 & 415 \\
\hline Peru & 0.11 & & & & & 368 & & 373 \\
\hline South Korea & 2.34 & 3.74 & 3,564 & 7,322 & 547 & 554 & 522 & 538 \\
\hline Taiwan & & & & & 549 & 560 & 532 & 523 \\
\hline Singapore & 2.02 & 2.15 & 4,835 & 7,513 & & 573 & & 551 \\
\hline $\begin{array}{l}\text { China } \\
\text { (Shanghai) }\end{array}$ & 0.95 & 1.79 & 749 & 2,138 & & 613 & & 580 \\
\hline Malaysia & 0.47 & 1.03 & 430 & 2,009 & & 421 & & 420 \\
\hline Thailand & 0.25 & 0.36 & 505 & 794 & 417 & 427 & 421 & 444 \\
\hline Indonesia & 0.05 & & 240 & & 391 & 375 & 393 & 382 \\
\hline
\end{tabular}

Sources R\&D expenditure and personnel: UNESCO Institute for Statistics database. http://data.uis. unesco.org. Accessed 15 December 2016; PISA: OECD PISA database. http://www.oecd.org/pisa/ data/. Accessed 15 December 2016

for International Student Assessment (PISA). The latter is the result of the examination of mathematics and science conducted among fifteen-year-old students. Table 4.1 clearly demonstrates that Latin American countries are far behind East Asian newly industrializing economies (NIEs) and China in terms of PISA scores and R\&D activities, but they are more or less on equal terms with Southeast Asian countries. As far as these data are concerned, it is natural to expect that the development of complex manufacturing industries is much slower in Latin American countries than in Asian NIEs.

\subsubsection{Fixed Capital Formation}

The development of machinery industries requires not only large R\&D expenditure but also major investment in production facilities to translate new knowledge into actual production. To direct a larger share of a country's national income toward investment, the national saving rate must be raised while consumption is restrained. Figure 4.4 reveals gross fixed capital formation and public/private consumption as shares of GDP in several Latin American and Asian countries. It is clear that the investment is much lower in Latin American countries. Only in 2011-13 was Chile's 
level of investment comparable with Malaysia's. In contrast, consumption, as indicated in the lower panel of Fig. 4.4, is higher in Latin America than in Asia. What characterizes Latin American consumption is that the share of household consumption is quite high.

Figure 4.5, comparing government social expenditures, also strongly suggests that a greater share of national economies has been directed toward consumption in Latin America than in Asia. The expansion of social expenditure can worsen the government's financial status to the extent that it hurts the entire national economy by crowding out the expenditure of public infrastructure investment, as has been observed in Brazil (Alston et al. 2010, p. 16, p. 39).

As for the delay of technological upgrading and the high level of consumption (and low level of investment) in Latin American countries, it could be argued that they have fallen into a vicious circle that serves to prolong their dependence on the natural resource sector and on the resource-processing sector, which are generally lower in technological sophistication. The vicious circle works in this way (Fig. 4.6): low investment in R\&D and facilities/equipment delays industrial upgrading; manufacturing industries' weakness, in turn, strengthens dependence on easy growth based on the export and processing of natural resources; the easily obtained (short-term) growth weakens incentives for restraining the current consumption and investing in industrial upgrading for the long run.

\subsubsection{Capacity to Coordinate}

To break the vicious circle just mentioned, the better coordination of stakeholders' interests is crucially important. Close cooperation between workers and employers helps to improve product and production technologies at the firm level, while interfirm coordination is crucial for broadening the value chain and/or fostering cluster development. Long value chains and robust clusters expectedly contribute to technological upgrading both in individual sectors and in the national economy as a whole.

For a look at the effectiveness of firm-level coordination, Table 4.2 presents the results of the World Economic Forum's executive survey on labor-employer cooperation. A smaller figure in the table signifies better performance (more cordial laboremployer relations). The table reveals that labor-employer relations have been generally more cooperative in Asia than in Latin America in both 2006-7 and 2016-17 except for in South Korea, which has especially poor labor-employer relations.

To measure interfirm relations, the four right-side columns of Table 4.2 indicate the ranks in cluster development and value chain breadth provided by the same executive survey. Again, the performance of Latin American countries is generally worse than that of their Asian counterparts. ${ }^{3}$

\footnotetext{
${ }^{3}$ Within Asia, Southeast Asian countries are lower than Asian NIEs, China, and India but are higher than Latin American countries in terms of performance.
} 

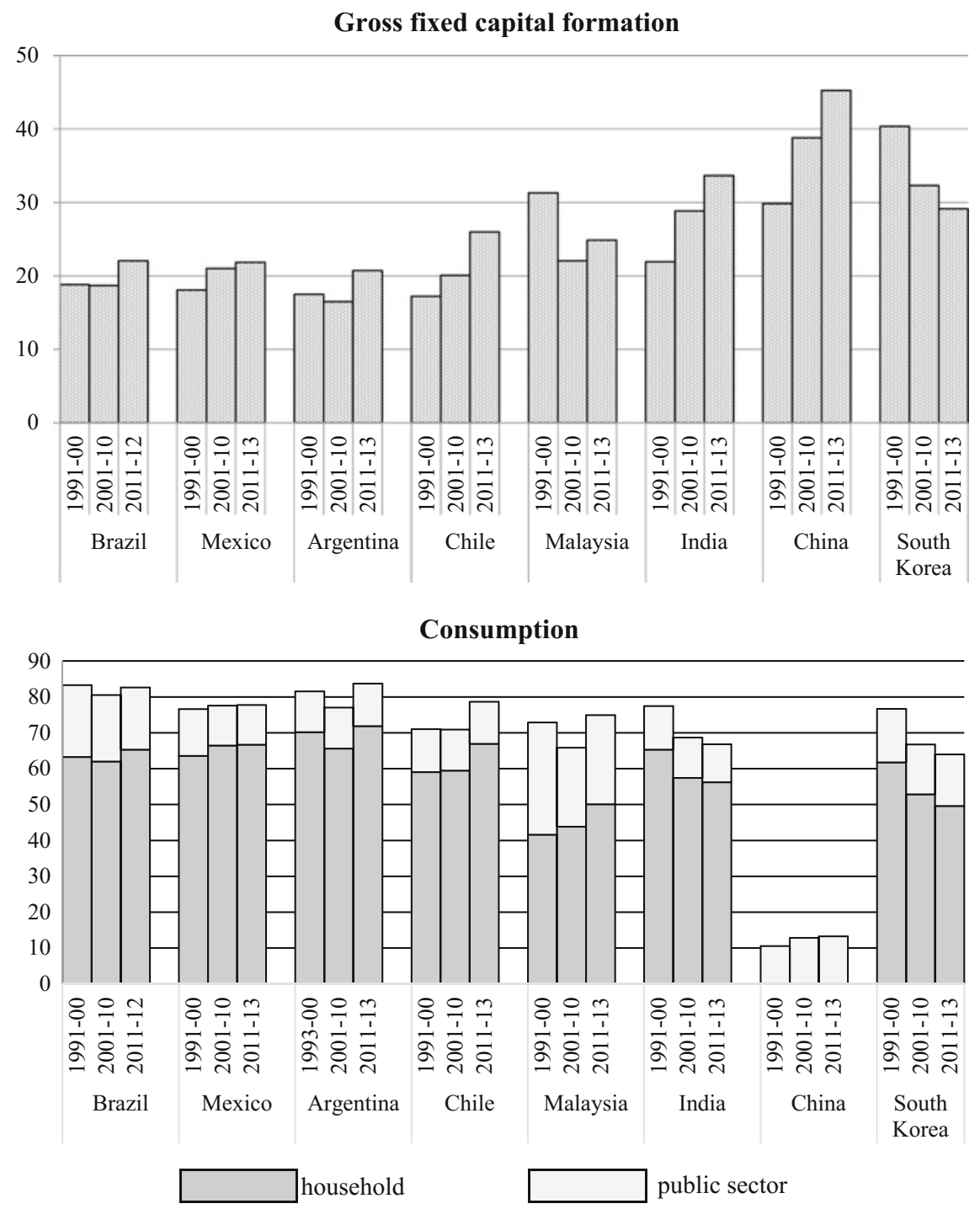

Fig. 4.4 Gross fixed capital formation and consumption as percentage of GDP. Note The dark gray columns in the consumption panel indicate household consumption whereas the light gray columns indicate public sector consumption. Source Constructed by the author on the basis of the national account data in constant local currency retrieved from the World Development Indicators database. http://databank.worldbank.org/data/reports.aspx?source=world-development-indicators. Accessed 5 August 2017

To complement the executive survey, Table 4.3 reveals the results of public opinion surveys concerning general interpersonal trust in the Latin American and Asian 


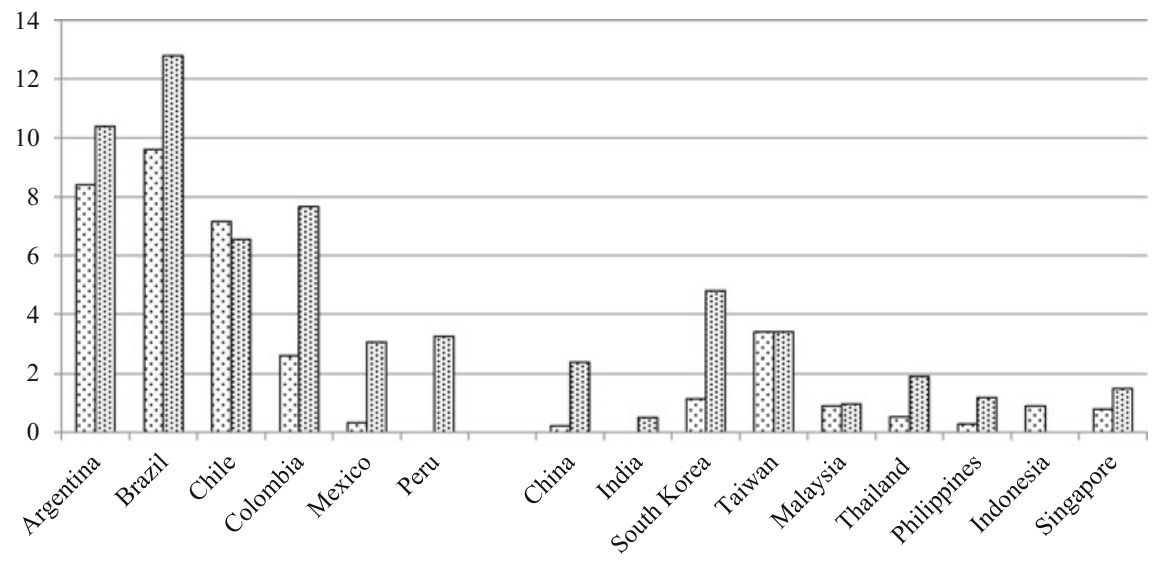

๑Public expenditure 1991-94 for Latin America and central government expenditure 1991-95 for Asia

면 2009-12 for Latin America and 2010-14 for Asia

Fig. 4.5 Government expenditure for social insurance and welfare (share of GDP, annual average). Note GDP of all of the countries except for India is for calendar year. Government expenditure is also for calendar year for all of the countries except for Taiwan (up to 2000), Thailand, and Singapore. Government expenditure of these countries and India is for fiscal year. Definition of "social insurance and welfare" differs from one country to another. Sources CEPAL (2016) and ADB (2010, 2016)

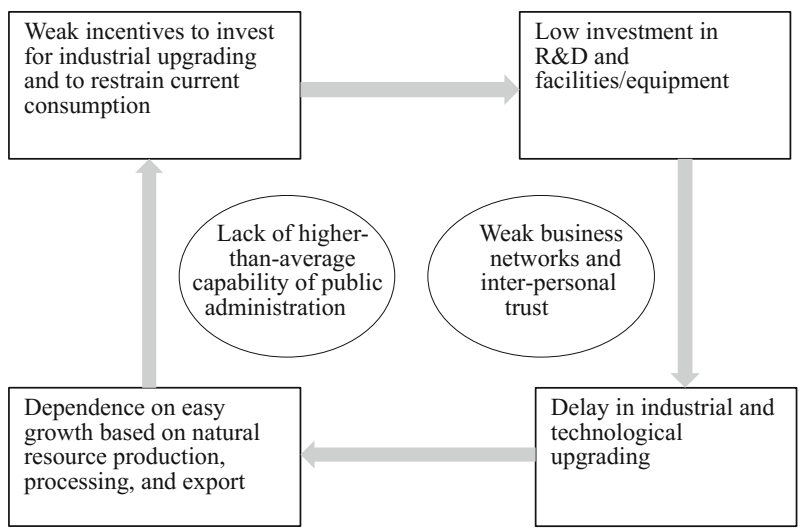

Fig. 4.6 Vicious circle in the economic development in Latin America. Source Constructed by the author

societies. Any societal coordination is expected to go more smoothly in a society in which interpersonal trust is higher. Table 4.3 clearly shows that interpersonal trust is much higher in Asian NIEs, China, and India than in Latin America, whereas the record of Southeast Asian countries is as poor as Latin American ones. 
Table 4.2 Rankings concerning labor-employer relations and business networks ${ }^{1}$

\begin{tabular}{|c|c|c|c|c|c|c|}
\hline & \multicolumn{2}{|c|}{$\begin{array}{l}\text { Cooperation in } \\
\text { labor-employer } \\
\text { relations }{ }^{2}\end{array}$} & \multicolumn{2}{|c|}{ Cluster development ${ }^{3}$} & \multicolumn{2}{|c|}{ Value chain breadth ${ }^{4}$} \\
\hline & 2006-07 & $2016-17$ & 2006-07 & $2016-17$ & 2006-07 & 2016-17 \\
\hline Argentina & 113 & 121 & 65 & 103 & 96 & 83 \\
\hline Brazil & 84 & 118 & 43 & 44 & 57 & 61 \\
\hline Chile & 29 & 57 & 34 & 94 & 62 & 60 \\
\hline Mexico & 45 & 52 & 41 & 35 & 46 & 34 \\
\hline Peru & 89 & 75 & 50 & 102 & 72 & 105 \\
\hline $\begin{array}{l}\text { South } \\
\text { Korea }\end{array}$ & 104 & 135 & 31 & 28 & 18 & 23 \\
\hline Taiwan & 14 & 16 & 5 & 3 & 19 & 21 \\
\hline Singapore & 1 & 3 & 7 & 12 & 17 & 10 \\
\hline China & 79 & 47 & 33 & 21 & 54 & 29 \\
\hline India & 53 & 67 & 14 & 27 & 22 & 26 \\
\hline Malaysia & 8 & 17 & 1 & 13 & 25 & 18 \\
\hline Thailand & 16 & 36 & 11 & 62 & 45 & 40 \\
\hline Indonesia & 40 & 45 & 40 & 29 & 68 & 36 \\
\hline Philippines & 86 & 27 & 47 & 66 & 36 & 49 \\
\hline $\begin{array}{l}\text { South } \\
\text { Africa }\end{array}$ & 112 & 138 & 39 & 30 & 76 & 52 \\
\hline
\end{tabular}

Source World Economic Forum, Global Competitiveness Index. https://www.weforum.org/reports. Accessed 27 September 2017

${ }^{1}$ The number of countries covered by the survey was 122 in 2006-7 and 138 in 2016-17

${ }^{2}$ Dependent on the answer to the survey question, "in your country, how would you characterize labor-employer relations?"

${ }^{3}$ Dependent on the answer to the survey question, "in your country, how widespread are welldeveloped and deep clusters?"

${ }^{4}$ Dependent on the answer to the survey question, "in your country, do companies have a broad or narrow presence in the value chain?"

As a whole, Latin American countries lag behind their Asian counterparts' (especially Asian NIEs, China, and India) with respect to the capacity of coordination among firms and people. Latin America's difficulty partially explains the nature of the Latin American economy, which Schneider (2013, Chap. 2) characterizes as "hierarchical capitalism." Extending the "varieties of capitalism" framework (Hall and Soskice 2001), Schneider insists that Latin American capitalism differs from the liberal market economy (the Anglo-Saxon countries), the coordinated market economy (Germany), and network capitalism (Japan). It is hierarchical in many senses. Family business owners or the headquarters of multinational corporations (MNCs) control business activities. In addition, the external (horizontal) influence of banks and shareholders is weak. Furthermore, many workers are informal or are of short tenure and subordinate to the management. Business groups do exist but consist of 
Table 4.3 Trust in people

\begin{tabular}{l|l|l}
\hline & $2002-04$ (annual average) & 2009 \\
\hline Argentina & 18 & 19 \\
\hline Brazil & 4 & 7 \\
\hline Chile & 14 & 15 \\
\hline Colombia & 18 & 19 \\
\hline Mexico & 19 & 24 \\
\hline Peru & 15 & 17 \\
\hline & 2003 or 2004 & 2006,07, or 08 \\
\hline South Korea & 55 & 67 \\
\hline Taiwan & $n . a$. & 40 \\
\hline Singapore & 34 & 30 \\
\hline China & 46 & 64 \\
\hline India & 28 & 40 \\
\hline Malaysia & 9 & 13 \\
\hline Thailand & 31 & 19 \\
\hline Indonesia & 21 & 26 \\
\hline Philippines & 10 & 13 \\
\hline Vietnam & 36 & 19
\end{tabular}

Note Share of people who answered "most people can be trusted" to the following question: "generally, do you think people can be trusted or do you think that you can't be too careful in dealing with people?"

Sources Latinobarómetro 2002, 2003, 2004, 2009; Asia Barometer 2003, 2004, 2006-07, 2008

firms covering diverse, mutually unrelated sectors. All in all, these characters impede fine and close coordination among market players.

\subsubsection{Intraregional Transaction}

The weakness of intrafirm connections is not confined to the domestic sphere but is also observed in the broader Latin American region. Latin America is conspicuously weak in intraregional business networks. In Asia, starting in the precolonial era, Chinese, Indian, and Arabian merchants developed regional trade networks (see relevant chapters in Volume I and Volume II). After World War II (especially after the 1980s), frequently relying on the existing business networks, Japanese manufacturers expanded their investment in the region and helped to develop production networks beyond national borders. East Asian NIEs, such as South Korea, Taiwan, Hong Kong, and Singapore, followed suit, further aiding the expansion of regional production networks and the concomitant enlargement of intraregional trade. Such expansion of regional investment, production, and trade has been crucial for each country's structural transformation. Each country has stepped up its industrial structure by 
transferring lower-value-added sectors to lower-income neighbors, specializing in higher-value-added sectors, and trading goods with regional partners.

Latin America has not benefited from such extensive production/trade networks and the concomitant structural transformation of individual economies. Figure 4.7 illustrates the difference clearly. The intraregional trade of the countries affiliated with the Organization of American States (OAS) is higher than the trade among the ASEAN plus Three (APT) countries. ${ }^{4}$ However, a close look reveals that NAFTA trade accounts for $73 \%$ of OAS trade. If NAFTA trade is excluded, intraregional trade is less than $15 \%$ of all trade of the OAS countries. In contrast, intra-ASEAN trade constitutes $25 \%$ of all trade of the ASEAN countries. Trade among APT countries amounts to $35 \%$ of their total trade. Even trade in Asia excluding intra-APT trade is greater than intraregional trade in the Western Hemisphere. The fact that non-APT trade in Asia is increasing indicates that the intraregional networks extend to outside of East Asia (into South Asia).

\subsubsection{Effectiveness of Public Administration}

Even if the societal capacity for coordination is low, the government may help. In fact, many governments have attempted to serve as intermediaries that coordinate economic and social interests. The literature on the developmental state or embedded autonomy (Johnson 1982; Wade 1990; Evans 1995; Weiss 1998) points out that the effectiveness of public administration is the main source of successful coordination. It is also important to notice that interest coordination is indispensable not only for technological upgrading but also for the mitigation of social disparity. The economic purpose of higher growth must be harmonized with the social purpose of the redistribution of the fruits of the growth. Such harmonization is impossible without serious government involvement. Specifically in Latin America, the governments must persuade various actors to restrain current consumption and to increase investment in technological education, $\mathrm{R} \& \mathrm{D}$, and production facilities while simultaneously reducing social disparity. They need to elaborate and implement the best policy mix for these purposes.

Figure 4.8 reveals the nature of public administration in the emerging states by plotting them according to two dimensions ${ }^{5}$ : regulatory quality and corruption control. Data come from the executive and specialist survey that the World Bank conducted. This figure indicates that Chile is as effective as Singapore and Taiwan are. Most other Latin American countries-Brazil, Mexico, Peru, Argentina, and Colombia-are less effective than South Korea and Malaysia are, but they are as effective as the Philippines, China, and India are. The effectiveness of public administration in Latin America does not seem to be noticeably inferior to that in Asia.

\footnotetext{
${ }^{4}$ All countries in the Western Hemisphere except for Cuba belong to the OAS.

${ }^{5}$ As for the definition and identification of the emerging states, refer to Tsunekawa's chapter in Volume I.
} 


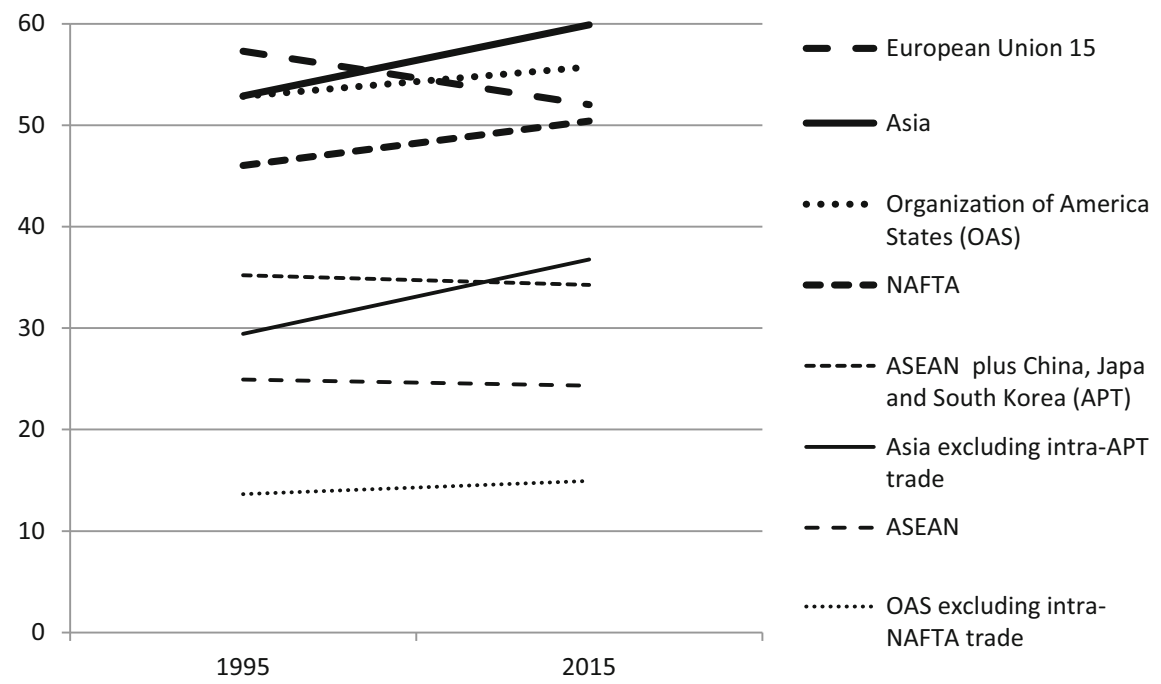

Fig. 4.7 Intraregional trade of goods (share of total exports of regional countries). Source Constructed by the author on the basis of the data retrieved from the UNCTAD database. http://unctadstat. unctad.org/wds/ReportFolders/reportFolders.aspx?sCS_ChosenLang=en. Accessed 20 September 2017

To examine a political environment for public administration, Fig. 4.9 plots the countries by their degrees of democracy and party fractionalization. When a country is more democratic and its party system is more fractionalized, the number of veto players is greater and makes the government subject to greater pressures for rent distribution, which makes effective interest coordination more complex and difficult. All Latin American countries are located in the upper right corner of Fig. 4.9, which means they are highly democratic and their party systems are fractionalized. In Asia, China, Singapore, and Malaysia are much less democratic and less fractionalized. However, India, Taiwan, South Korea, Thailand, and the Philippines share the same space as Latin American countries in Fig. 4.9. Again, the latter are not necessarily more disadvantageous than the former with respect to the political environment for effective public administration.

These results of my analysis indicate that Latin American countries' public administration is of average quality and capability, neither superior nor significantly inferior to that in Asian countries. However, in the face of weak societal trust and coordination 


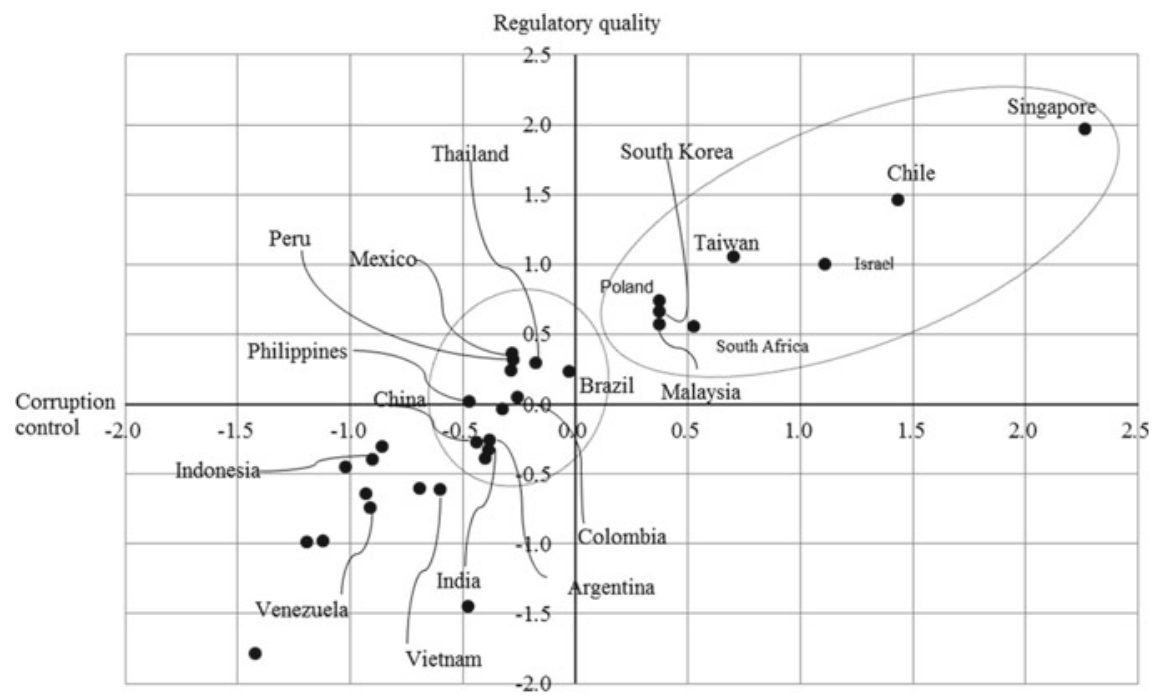

Fig. 4.8 Effectiveness of public administration, 1996-2006 (annual average scores). Source Constructed by the author based on data retrieved from World Bank's Worldwide Governance Indicators database, 2016 update. http://info.worldbank.org/governance/wgi/wgidataset.xlsx. Accessed 6 July 2017

capability, such ordinary administration is not adequate for breaking the strenuous vicious circle of resource dependence and low technological investment. As Latin American countries face greater challenges with the interest coordination needed to achieve technological upgrading and social equity simultaneously, their public administration must be much better than average.

\subsection{Root Causes: Historical Legacies}

All of the second-order causes of the low performance of Latin American economies - an economic vicious circle, weak societal trust and business networks, and public administration of average quality-have strong historical roots. 


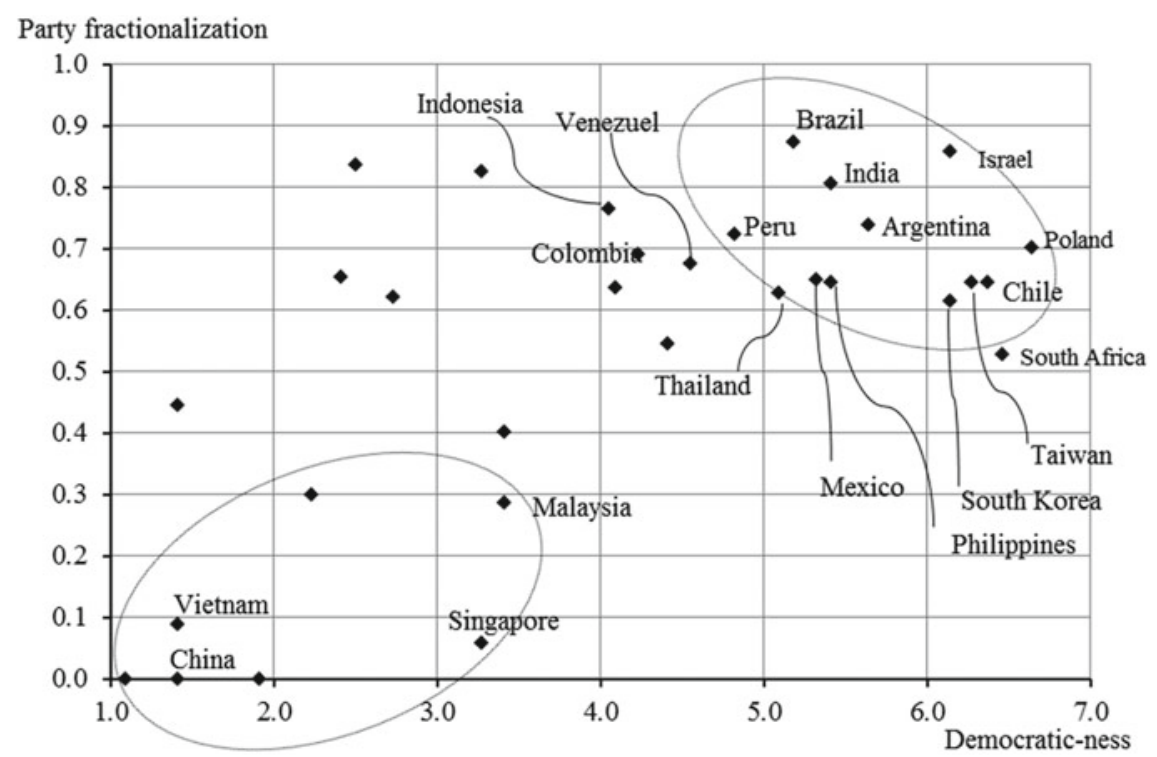

Fig. 4.9 Democratic-ness and party-system fractionalization, 1996-2006 (annual average scores). Sources Constructed by the author based on data retrieved from Freedom House, "Individual Country Ratings and Status, 1973-2015 (FINAL)" and Cross-National Time-Series Data Archive, 2017 edition

\subsubsection{High Inequality and Weak Trust}

Latin America has been notorious for social disparity. The GINI index exceeded 0.5 in many countries as late as the 1990s. ${ }^{6}$ Such enormous region-wide inequality cannot be understood unless the extremely unequal society inherited from the colonial era is taken into consideration.

During this period, the owners of large estates and mines exploited native and African workers for agricultural and mining production. Although the population of mixed-bloods increased throughout the colonial period, ${ }^{7}$ the society continued to be highly unequal, with the minority urban white population surrounded by huge masses of natives, Africans, and mixed-bloods. This situation was in sharp contrast with most of the Asian region, where the small-farmer economy and native societal networks survived mostly intact under the indirect rule of Western colonial rulers.

Although many Latin American countries gained independence during the first twenty-five years of the nineteenth century, domination by the white minority persisted well into the twentieth century. Native villages lost more lands due to the

\footnotetext{
${ }^{6}$ Based on the PovcalNet data available at http://iresearch.worldbank.org/PovcalNet/ povOnDemand.aspx, accessed December 20, 2016.

${ }^{7} \mathrm{By}$ the end of the eighteenth century, $18 \%$ of the Mexican population were of mixed blood (Brading 1985, p. 241).
} 
liberal reforms introduced during the nineteenth century, and a greater number of villagers took outside jobs as laborers. As the rural areas had come to feature surplus population by the eighteenth century due to population growth (Gibson 1984, p. 405), taking jobs at large estates or urban centers did not necessarily mean the deterioration of laborers' living conditions (Bauer 1985, pp. 276-277). However, the people left behind in the villages continued to live harsh, impoverished lives. Land reform in Mexico and Peru did not help to improve the situation because it only contributed to creating a large number of poor unproductive peasants.

On the other hand, elites frequently mobilized poor and uneducated people, especially those in urban areas, as militias or as supporters of populistic politics. The result was an extremely divisive society in which the elites and the masses had different outlooks on their economic and social lives and distrusted each other. At the same time, elites fought among themselves for political hegemony on the basis of their personalist power bases in the population.

In this kind of society, it is hard to expect the development of strong social bonds. Neither is it easy to expect the expansion of long-term relations among business firms beyond close family confines. Schneider observes that families owned and managed $90 \%$ of the thirty-three largest business groups in Latin America as late as the 2000s (Schneider 2013, p. 10, 44). Additional evidence of family dominance is the lack of market capitalization in Latin America. According to Barbara Stallings (2006, p. 124), the average market capitalization in the seven largest economies of Latin America was a mere $34 \%$ of GDP in 2003 in contrast with $80 \%$ in seven developing countries in East Asia. ${ }^{8}$ The average turnover ratios in the two regions were 20 and $152 \%$ respectively. Between 1990 and 2003, the number of listed firms in the seven Latin American countries declined from 1,624 to 1,238, but it expanded from 1,792 to 4,576 in East Asia.

\subsubsection{Weak Intraregional Business Networks}

The weak intraregional connections also originate from the colonial era. The Spanish monarchy prohibited direct commerce among various parts of the empire. Commercial activities were restricted to the Spanish merchants who operated with a royal charter and under home-country control. In practice, the large contraband transactions of local and foreign traders undermined the Spanish monopoly, and intraregional trade flourished (Macleod 1984; Clayton 1985). The situation was more or less similar in Brazil (Marquez 2006, pp. 404-405). Nevertheless, Spain and Portugal attempted to re-impose trade restrictions on their colonies from time to time and jeopardized regular and profitable intraregional transactions (Marquez 2006, p. 420).

\footnotetext{
${ }^{8}$ The seven Latin American countries are Argentina, Brazil, Chile, Colombia, Mexico, Peru, and Venezuela. The Asian counterparts are Indonesia, South Korea, Malaysia, the Philippines, Singapore, Taiwan, and Thailand.
} 
This constraint was removed after the independence of Latin American countries. However, toward the end of the nineteenth century, the economic development of Latin American countries increasingly depended on the export of agricultural and mining resources to Europe and the United States, which were experiencing rapid industrialization (Bulmer-Thomas 2003, Chap. 3). No economic incentive to build close business ties within the continent existed.

The lack of intraregional business networks persisted and was even strengthened when Latin American countries entered the period of industrialization. The import substitution industrialization (ISI) that began around World War II did not lead to the development of the regional production networks seen in Asia, as each Latin American country attempted to promote similar manufacturing industries. Rather than cooperating, they competed and built separate autarchic economies. After the 1960s, some Latin American countries agreed on industrial complementarity arrangements (IADB 1984, pp. 156-157), ones similar to ASEAN's Brand-to-Brand Complementation and ASEAN Industrial Cooperation. The Latin American arrangements, however, did not contribute to increasing intraregional trade to any significant degree.

When ISI faced limitations and the debt crisis struck Latin American countries, they dissolved a large part of the protection regime and adopted highly market-oriented policies (IADB 1997). However, such policies only brought them back to the nineteenth century status of resource-dependent countries with weak intraregional ties.

\subsubsection{Public Administration of Average Quality}

The colonial legacy can also be observed in the nature of public administration in Latin America. During the colonial period, Spanish or Portuguese monarchs appointed high-ranking public officials and sent them from the Iberian Peninsula. In practice, an increasing number of public posts were sold to native white people (creoles) who had accumulated wealth. By the latter half of the eighteenth century, creoles even occupied the majority of the membership of the audiencia (the highest public institution in Spanish America) in major cities (Brading 1984, p. 404; 1985, p. 250). The situation was similar in Brazil. The tradition of extensive political appointment has persisted in Latin America since then.

For instance, 20,000 public posts were traditionally at the president's discretion in Brazil. Then, the government of the leftist Lula da Silva, which ruled the country between 2003 and 2010, added 2,700 to them (Reid 2014,p. 148). Public posts in local governments inflate the total number of political appointees. Schneider estimates that political appointees total 50,000 each in Brazil and Mexico. This kind of practice has obstructed the development of professional bureaucracy (Schneider 1999, p. 291).

Political instability and the frequent changes in government after independence also dampened efforts to build a professional bureaucracy. This instability partially stemmed from the introduction (in the Spanish America) of the constitutional model of people's sovereignty and the separation of powers at the moment of independence 
(Lockhart and Schwartz 1983, p. 425; Safford 1985, p. 358). Because the Spanish monarchy had ruled its colonies with no tradition of such power separation, the sudden introduction of the power separation system only led to further political strife and resultant instability.

Moreover, the war of independence in Latin America was fought against remote external forces in many separate parts of the vast continent and consequently did not work as an integrative influence in the way that Tilly $(1975,1990)$ attributed the formation of strong national states in Europe to the war with neighboring states. Nor did interstate wars after independence help to strengthen the governing machine, as they were generally small in scale and intensity (Centeno 2002, Chap. 2). Without sufficient incentives for the formation of a well-organized and financed bureaucracy with strong authority, Latin American countries have not been able to build a bureaucracy with more than average quality.

\subsubsection{High Consumption, Low Investment}

It should be noted that before the 1960s Latin American countries enjoyed GDPs per capita that were much higher than Asian countries'. The high performance of Latin American economies had been brought about by the first phase of "emerging" (or speedy catchup) based on the commodity boom in the late nineteenth century and the early twentieth century, and then by the second phase of the catchup that the ISI stimulated in the 1940s-60s. The resultant economic prosperity and the expansion of manufacturing industries contributed to increasing the working population and raising labor wages.

On the other hand, the gradual enhancement of democratic practices since around World War I enhanced opportunities for the labor movement. After the 1930s, an increasing number of middle-class or even upper-class politicians began to employ populistic policies to mobilize organized labor's support (Conniff 1982, 2012; De la Torre and Arnson 2013; Haber 2006). As a result, social security schemes for pensions and health care were expanded, at least for formal-sector employees, and government subsidies for energy and food benefited the general public. ${ }^{9}$ As displayed in Fig. 4.5, government expenditures for social insurance and welfare were much higher in Latin American countries than in Asian ones even in the 2010s, even though many Latin American countries had introduced highly market-oriented reforms by then.

High wages and high social security benefits led to prematurely high consumption, which ate up the national wealth that should have been used for investment. However, as the rich resource endowment facilitated easy economic growth, the structure of high consumption and low investment was left untouched, thus deepening the vicious circle of resource dependence and the delay in technological upgrading.

\footnotetext{
${ }^{9}$ Although the social security system improved for labor union members under both democratic and semidemocratic regimes, the pressure to expand social programs beyond the formal sector was very weak (Haggard and Kaufman 2008, pp. 111-113).
} 


\subsection{Conclusion}

Although many Latin American countries have achieved the economic growth rates that are higher than that of the United States in the past quarter century, their catchup speed has had a much poorer record than their Asian counterparts'. To elucidate the causes of the different performance levels between Latin America and Asia, I explored three levels of causes in this chapter.

The first-order, mostly economic cause is the degree of industrial and technological upgrading. Latin American countries are increasingly dependent on the production, processing, and export of natural resources, whereas Asian economies, especially East Asian NIEs and China, have upgraded their industrial structures by shifting to machinery industries, which are technologically more sophisticated and economically more value added.

To explore deeper causes of the difference in performance between Latin America and Asia, I examined mostly political economy-focused second-order factors. Latin America has fallen into the vicious circle of high resource dependence and low investment in industrial and technological upgrading because they lack the sufficient societal trust, dense business networks within and beyond national borders, and effective public administration that could help to foster interest coordination for industrial and technological upgrading.

Further exploration revealed that the political economy-related causes of Latin American countries' poor economic performance have deeper roots in their histories. Their political economies, characterized by weak societal and business connections, public administration of average quality, and relatively high consumption levels, were all formed and reinforced by historical experiences during the colonial period, the immediately postindependence period, the late nineteenth and early twentieth centuries, and the ISI period. Latin American countries struggle to break heavy weights of its historical legacies.

\section{References}

ADB (Asian Development Bank). 2010. Key Indicators for Asia and the Pacific 2010. Manila: ADB. ADB (Asian Development Bank). 2016. Key Indicators for Asia and the Pacific 2016. Manila: ADB.

Alston, Lee J., Bernardo Mueller, Marcus Andre Melo, and Carlos Pereira. 2010. The Political Economy of Productivity in Brazil. IDB Working Paper (21). Washington, D.C.: Inter-American Development Bank.

Bauer, Arnold J. 1985. Rural Workers in Spanish America: Problems of Peonage and Oppression. In Readings in Latin American History Volume II: The Modern Experience, ed. Peter J. Bakewell, John J. Johnson, and Meredith D. Dodge, 258-283. Durham: Duke University Press.

Brading, David A. 1984. Bourbon Spain and Its American Empire. In The Cambridge History of Latin America Volume I: Colonial Latin America, ed. Leslie Bethell, 389-439. Cambridge: Cambridge University Press. 
Brading, David A. 1985. Government and Elite in Late Colonial Mexico. In Readings in Latin American History Volume I: The Formative Centuries, ed. Peter J. Bakewell, John J. Johnson, and Meredith D. Dodge, 241-260. Durham: Duke University Press.

Bulmer-Thomas, Victor. 2003. The Economic History of Latin America Since Independence, 2nd ed. Cambridge: Cambridge University Press.

Centeno, Miguel Angel. 2002. Blood and Debt: War and the Nation-State in Latin America. University Park, Pennsylvania: The Pennsylvania State University Press.

CEPAL (Comisión Económica para América Latina y el Caribe). 2016. Panorama Social de América Latina 2015. Santiago: CEPAL.

Clayton, Lawrence A. 1985. Trade and Navigation in the Seventeenth-Century Viceroyalty of Peru. In Readings in Latin American History Volume I: The Formative Centuries, ed. Peter J. Bakewell, John J. Johnson, and Meredith D. Dodge, 174-191. Durham: Duke University Press.

Conniff, Michael L. (ed.). 1982. Latin American Populism in Comparative Perspective. Albuquerque: University of New Mexico Press.

Conniff, Michael L. (ed.). 2012. Populism in Latin America, 2nd ed. Tuscaloosa: The University of Alabama Press.

De la Torre, Carlos and Cynthia J. Arnson, eds. 2013. Latin American Populism in the Twenty-First Century. Washington, D.C.: Woodrow Wilson Center Press.

Evans, Peter. 1995. Embedded Autonomy: States and Industrial Transformation. Princeton: Princeton University Press.

Gibson, Charles. 1984. Indian Society Under Spanish Rule. In The Cambridge History of Latin America Volume II: Colonial Latin America, ed. Leslie Bethell, 381-419. Cambridge: Cambridge University Press.

Haber, Stephan. 2006. The Political Economy of Industrialization. In The Cambridge Economic History of Latin America Volume II: The Colonial Era and the Short Nineteenth Century, ed. Victor Bulmer-Thomas, J. H. Coatsworth, and R. C. Conde, 537-584. Cambridge: Cambridge University Press.

Haggard, Stephen, and Kaufman. 2008. Development, Democracy, and Welfare States: Latin America, East Asia, and Eastern Europe. Princeton: Princeton University Press.

Hall, Peter, and David Soskice. 2001. Varieties of Capitalism: The Institutional Foundations of Comparative Advantage. Oxford: Oxford University Press.

IADB (Inter-American Development Bank). 1984. Economic and Social Progress in Latin America: Background and Prospects. Washington, D.C.: IADB.

IADB (Inter-American Development Bank). 1997. Latin America After a Decade of Reforms. Washington, D.C.: IADB.

Johnson, Chalmers. 1982. MITI and the Japanese Miracle: The Growth of Industrial Policy, 1925-1975. Stanford: Stanford University Press.

Kohli, Harinder S., Ashok Sharma, and Anil Sood, eds. 2011. Asia 2050: Realizing the Asian Century. Los Angeles, London, New Delhi, Singapore, Washington, D.C.: Sage Publications.

Lochhart, James, and Stuart B. Schwartz. 1983. Early Latin America: A History of Colonial Spanish America and Brazil. Cambridge: Cambridge University Press.

Macleod, Murdo J. 1984. Spain and America: The Atlantic Trade 1492-1720. In The Cambridge History of Latin America Volume I: Colonial Latin America, ed. Leslie Bethell, 341-388. Cambridge: Cambridge University Press.

Marquez, Graciela. 2006. Commercial Monopolies and External Trade. In The Cambridge Economic History of Latin America Volume I: The Colonial Era and the Short Nineteenth Century, ed. Victor Bulmer-Thomas, John H. Coatsworth, and Roberto Cortes-Conde, 395-422. Cambridge: Cambridge University Press.

Reid, Michael. 2014. Brazil: The Troubled Rise of a Global Power. New Haven and London: Yale University Press.

Safford, Frank. 1985. Politics, Ideology and Society in Post-Independence Spanish America. In The Cambridge History of Latin America Volume III: From Independence to c. 1870, ed. Leslie Bethell, 347-421. Cambridge: Cambridge University Press. 
Schneider, Ben Ross. 1999. The Desarrollista State in Brazil and Mexico. In The Developmental State, ed. Meredith Woo-Cumings, 276-305. London and Ithaca: Cornell University Press.

Schneider, Ben Ross. 2013. Hierarchical Capitalism in Latin America: Business, Labor, and the Challenges of Equitable Development. New York: Cambridge University Press.

Stallings, Barbara. 2006. Finance for Development: Latin America in Comparative Perspective. Washington, D.C.: Brookings Institution Press.

Tilly, Charles (ed.). 1975. The Formation of National States in Western Europe. Princeton: Princeton University Press.

Tilly, Charles. 1990. Coercion, Capital, and European States, AD 990-1992. Oxford: Blackwell.

Wade, Robert. 1990. Governing the Market: Economic Theory and the Role of Government in East Asian Industrialization. Princeton: Princeton University Press.

Weiss, Linda. 1998. The Myth of the Powerless State: Governing the Economy in a Global Era. Cambridge: Polity Press.

Open Access This chapter is licensed under the terms of the Creative Commons AttributionNonCommercial-NoDerivatives 4.0 International License (http://creativecommons.org/licenses/bync-nd/4.0/), which permits any noncommercial use, sharing, distribution and reproduction in any medium or format, as long as you give appropriate credit to the original author(s) and the source, provide a link to the Creative Commons license and indicate if you modified the licensed material. You do not have permission under this license to share adapted material derived from this chapter or parts of it.

The images or other third party material in this chapter are included in the chapter's Creative Commons license, unless indicated otherwise in a credit line to the material. If material is not included in the chapter's Creative Commons license and your intended use is not permitted by statutory regulation or exceeds the permitted use, you will need to obtain permission directly from the copyright holder.

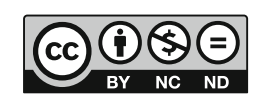

